\title{
Breeding for Promiscuous Soybeans at IITA
}

\author{
Hailu Tefera \\ International Institute of Tropical Agriculture (IITA), Chitedze Agricultural Research \\ Station, P.O.Box 30258, Lilongwe \\ Malawi
}

\section{Introduction}

Soybean [Glycine max (L.) Merrill] is an annual legume that belongs to the legume family Fabaceae. It is a strictly self-pollinating legume with $2 n=40$ chromosomes. With $40 \%$ protein, $20 \%$ oil and $30 \%$ carbohydrate, soybean plays a very significant role in world agriculture. World demand for soybean has been able to absorb ever-increasing production at prices that are profitable to producers. Since 1970, world consumption of soybeans has grown at an annual rate of $4.8 \%$ on average and since the 1990s it showed an annual increase of $5.4 \%$ on the average (Flaskerud, 2003). The world's major supply of edible oil comes from soybean and it is likely that the trend will continue in the future. Soybean is also the major source of protein rich feed component for livestock, poultry, pig and fish farms.

According to three-year (2006-2008) average data of FAOSTAT, 94.1 million hectares were allocated to soybean production in the world and 222.9 million tons of grain were obtained (http://faostat.fao.org/site/567/DesktopDefault.aspx?PageID=567\#ancor; Accessed 29 August 2010). For the same period, world average yield per ha was $2371 \mathrm{~kg}$. Considering different continents of the world, Latin America had the highest area (41 million ha) and production (109.5 million tons) followed by North America with 30 million ha and 82 million tons. In the third place was Asia with 19.8 million ha and 26.8 million tons. The same data source showed that Africa's soybean area (1.3 million ha) and production (1.4 million tons) was the lowest in the world. In terms of productivity per unit area, the highest $2742 \mathrm{~kg}$ ha-1 was from North America followed by South America (2673 kg ha-1), Europe (1517 kg ha$\left.{ }^{1}\right)$, and Asia (1351 kg ha-1). Africa's average productivity per unit area (1073 kg ha-1) was the lowest among the continents and it was in fact, $45 \%$ of the world's average. Pertaining to individual countries, the main producer of soybean in the world is USA and in the second and third places are Brazil and Argentina. These countries are followed by China and India. Average data (2006-2008) of FAOSTAT showed that area harvested in USA, Brazil and Argentina was 28.8, 21.3 and 15.8 million ha, respectively. The corresponding production figures were 79, 56.7 and 44.7 million tons for USA, Brazil and Argentina, respectively.

Not less than 22 African countries produce soybean in varying quantities (Table 1). However, some soybean producing countries are not captured in FAOSTAT. A good example is Ghana where there is sizeable soybean production. The highest three-year (2006-2008) average production of 592,000 tons on an area of 625,667 ha was from Nigeria (Table 1). In the second place was South Africa with an average total production of 317,332 tons from 199,323 ha. Uganda was in the third place with 176,333 tons from 146,667 ha. Zimbabwe and Malawi were 
in the fourth and fifth place by producing 96,008 and 50,000 tons from 60,679 and 71,333 ha, respectively. Other African countries with an average of more than 10,000 tons of production were Rwanda, Egypt, DR Congo, Zambia, and Benin. The total production of soybean in Africa, which was elevated to 1.4 million tons by 2008 was merely 0.2 million tons when IITA started to improve soybean in Africa and average yield was $660 \mathrm{~kg} \mathrm{ha}^{-1}$. By the year 2008, average yield for Africa increased by $67 \%$ to 1.1 tons ha-1. The development of adapted promiscuously nodulating tropical germplasm and distribution to various African countries contributed to increase soybean production in Africa.

\begin{tabular}{lrrr}
\hline \multicolumn{1}{c}{ Country } & Area (ha) & Production (tons) & Yield (kg ha-1) \\
\hline Nigeria & 625667 & 592000 & 946 \\
South Africa & 199323 & 317332 & 1578 \\
Uganda & 146667 & 176333 & 1202 \\
Zimbabwe & 60679 & 96008 & 1574 \\
Malawi & 71333 & 50000 & 700 \\
Rwanda & 42788 & 27046 & 632 \\
Egypt & 7981 & 25932 & 3242 \\
DR Congo & 33492 & 16177 & 483 \\
Zambia & 10000 & 12000 & 1200 \\
Benin & 18820 & 10711 & 625 \\
Cameroon & 12000 & 7000 & 583 \\
Ethiopia & 6826 & 6685 & 971 \\
Burkina Faso & 5177 & 5853 & 1130 \\
Mali & 3274 & 4131 & 1342 \\
Liberia & 7867 & 3183 & 404 \\
Burundi & 3700 & 3000 & 822 \\
Gabon & 2100 & 2200 & 1047 \\
Kenya & 2504 & 2092 & 835 \\
Tanzania & 5000 & 1900 & 380 \\
Morocco & 1000 & 1000 & 1000 \\
Côte d'Ivoire & 683 & 686 & 1015 \\
Madagascar & 50 & 50 & 1000 \\
\hline
\end{tabular}

Table 1. Three-year (2006-2008) average area, production and yield of soybean in soybean producing countries of Africa (Source:

http://faostat.fao.org/site/567/DesktopDefault.aspx?PageID=567\#ancor; Accessed 29 August 2010)

\section{Why soybean was considered by IITA?}

The International Institute of Tropical Agriculture (IITA) started soybean improvement around 1974. The main reason to consider soybean was that there was little effort in improving this crop in Africa and as a result yield was extremely low (less than 0.5 ton per hectare). Other associated impediments were low seed viability, poor nodulation with native Rhizobium available in the soil and high shattering in the moist and dry savanna zones. Post harvest utilization of the crop was also limited as recipes suitable to small-scale farmers in Africa were not developed. These being the predicaments, IITA capitalized on 
some of the opportunities soybean can provide to tropical agriculture. Preliminary yield trial carried out on soybean germplasm materials in 1974 revealed that yields were high as compared to other legumes. Of the genotypes included in the trial, TGm 249-3 gave the highest yield of $3615 \mathrm{~kg} \mathrm{ha}^{-1}$ (Dashiell et al., 1987). The excellent performance of soybean under tropical Africa condition was also a contributory factor to venture into soybean improvement. On top of being an excellent source of quality protein and vegetable oil, the existence of ample genetic diversity to solve some of the major constraints like poor seed longevity and efficient natural nodulation were reasons to invest in soybean. Moreover, in the 1970s some National Agricultural Research Systems (NARS) showed immense interest and commitment to expand soybean production and utilization. All these constraints and opportunities led IITA to engage in soybean improvement for over three decades.

\section{Soybean growing agro-ecologies in Africa}

IITA considered three major agro-ecological zones in Africa in the course of variety development. The main one was the moist savanna zone. Efforts were also made to develop soybean production technologies in the Sudan savanna and mid-altitude zones. The moist savanna zone covers an area of approximately 5.6 million $\mathrm{km}^{2}$, representing $29 \%$ of the total crop land in sub-Saharan Africa (SSA). This zone is characterized by a growing period of 150 to 270 days (IITA, 2000). The moist savanna zone has high potential for crop and livestock production, and is widely viewed as the emerging bread-basket of sub-Saharan Africa. Favorable circumstances in this zone include: relatively good soils, high solar radiation, adequate rainfall, and relatively low disease and insect pressures. Soybean trials have been conducted at Zaria and Mokwa locations in Nigeria in this zone. These two locations represent different agro-ecological zones of the moist savanna (Table 2). Zaria lies in the northern Guinea savanna zone with a mean annual rainfall of about $900 \mathrm{~mm}$ per year concentrated almost entirely from June to September. Mokwa is situated in the southern Guinea savanna with a mean rainfall of about $1100 \mathrm{~mm}$ per year (Sanginga et al., 2000).

Sudan savanna zone receives about $600 \mathrm{~mm}$ rainfall (IITA, 1999). Low moisture stress during growth and development of soybean is a constraint in this zone and the development of extra-early and drought tolerant varieties have been the major focus. In this zone, soybean trials are carried out at Minjibir Farm, Kano (Table 2). The mid-altitude zone covers about $40 \%$ of the land area in sub-Saharan Africa mainly in eastern and southern Africa (IITA, 2000). The mid-altitude ecologies also have conditions favorable for high yields, including cool temperatures that permit good crop growth, adequate rainfall in most areas, and some fertile volcanic soils. The main soybean breeding location for this zone is located at Chitedze Agricultural Research Station in Lilongwe, Malawi.

\section{Why breeding for promiscuous nodulation?}

Breeding for promiscuous nodulating genotypes was one of the approaches IITA followed to enhance biological nitrogen fixation of tropical soybeans. Soybeans that nodulate effectively with diverse indigenous rhizobia are considered as promiscuous, and the characteristic promiscuity (Kuneman et al., 1984). Hence, promiscuous genotypes of soybean form symbiotic association with available Rhizobium strains in the soil and thus fix atmospheric nitrogen whilst non-promiscuous genotypes need specific rhizobial strains to fix nitrogen from the air. In Africa cowpea-type rhizobia are indigenous and are abundant. 
In the late 1970s, breeders at IITA observed that most high yielding soybean cultivars from USA have specific requirements for Rhizobium japonicum (Pulver et al., 1982) and inoculation of these varieties was found to be essential when growing them under tropical conditions of low soil nitrogen. In the early 1980s, it was assumed that most tropical countries did not have the facilities and personnel required for inoculum production, storage, and distribution and were dependent upon importation of the final product (Pulver et al., 1982). The nonabundance of commercial $R$. japonicum inoculants and nitrogenous fertilizers led to the option of breeding promiscuous cultivars in IITA since soybean genotypes that do form symbiotic association with indigenous cowpea-type rhizobia were identified. Generally, soybean varieties developed for promiscuous nodulation with the indigenous rhizobia were considered to increase production of soybean in tropical Africa with minimum cost affordable to small-scale farmers.

\begin{tabular}{|c|c|c|c|c|}
\hline Location & Coordinates & $\begin{array}{l}\text { Elevation } \\
\quad \text { (masl) }\end{array}$ & $\begin{array}{l}\text { Rainfall (long- } \\
\text { term average) } \\
(\mathrm{mm})\end{array}$ & Vegetation \\
\hline $\begin{array}{l}\text { Mokwa, } \\
\text { Nigeria }\end{array}$ & $6^{\circ} 5^{\prime} \mathrm{N}, 9 \circ 48^{\prime} \mathrm{E}$ & 308 & 900 & $\begin{array}{l}\text { Southern Guinea } \\
\text { savanna }\end{array}$ \\
\hline Zaria, Nigeria & $11^{\circ} 11^{\prime} \mathrm{N}, 7 \circ 38^{\prime} \mathrm{E}$ & 685 & 1100 & $\begin{array}{l}\text { Northern Guinea } \\
\text { savanna }\end{array}$ \\
\hline Kano, Nigeria & $12 \circ 47 \mathrm{~N}, 9 \circ 2 \mathrm{E}$ & 700 & 600 & Sudan savanna \\
\hline $\begin{array}{l}\text { Chitedze, } \\
\text { Malawi }\end{array}$ & $15^{0} 55^{\prime} \mathrm{S}, 35^{0} 04^{\prime} \mathrm{E}$ & 1146 & 892 & Plateau \\
\hline
\end{tabular}

Table 2. Some characteristics of soybean breeding locations in sub-Saharan Africa

\section{Identification of promiscuously nodulating soybean germplasm}

Observation on nodulation of some soybean cultivars in soils where soybean has not been cultivated previously and the non-nodulation of exotic varieties that were bred in the USA indicated the existence of genotypic variation in soybean for the ability to recognize and form symbiosis with diverse species of rhizobia. Pulver et al. (1982) reported genotypic variation in six soybean genotypes in their ability to form an effective symbiosis with local Rhizobium spp. These workers noted that local cultivars were more promiscuous as compared to improved cultivars from the USA. IITA screened 400 geographically diverse soybean germplasm accessions for their compatibility with indigenous rhizobia in a range of tropical environments and assessed the efficiency of symbiosis under greenhouse and field conditions (Pulver et al., 1985). Of the 400 genotypes screened for promiscuity, 10 germplasm accessions were found forming effective symbiotic relationships with the soil rhizobia at five locations in Nigeria. The source of these germplasm accessions were tropical Africa and south East Asia.

\section{Breeding objectives and methodology}

The main goal of soybean improvement at IITA has been to develop high yielding promiscuous and stable soybean varieties that are tolerant or resistant to biotic and abiotic constraints. Specific objectives set in their chronological order since the inception of soybean 
improvement have been a) improving grain yield of promiscuous genotypes has been the main objective from the outset and still it is a top priority in soybean breeding and crop management at present as overall soybean yield in Africa is low in comparison to other continents; b) biological nitrogen fixation (BNF); c) pod shattering- this trait has been given top priority because it was found out that farmers lose their entire crop if they do not harvest as soon as the crop is mature; d) seed longevity and color; e) Diseases- the main ones are soybean rust, red leaf blotch, frog eye leaf spot, bacterial pustule, bacterial blight, and soybean viruses; f) insect pests that included pod sucking bugs and defoliating insects; g) resistance to lodging; $h$ ) tolerance to low Phosphorus; i) drought tolerance; $j$ ) Striga reduction ability through suicidal germination; and k) dual-purpose soybeans suitable for grain as well as fodder for livestock.

The soybean breeding program at IITA from its inception has focused on combining the yield potential of cultivars bred in North America with the 'promiscuous' or 'naturallynodulating' ability of landraces from Asia to form nodules and fix nitrogen without inoculation in African soils (Giller \& Dashiell, 2006). Hybridization and selection have been the main methodology in developing varieties over the years. Excellent facility has been established at IITA-Ibadan to accomplish this task. Pedigree method of selection is followed to advance segregating populations by raising two generations per year - one during the main growing season and the second through off-season irrigation. Selection in the $F_{2}$ and $F_{3}$ generations are restricted to selecting good individual plants and discarding single plants and progeny rows susceptible to diseases such as bacterial pustule, frog-eye leaf spot and rust. In $\mathrm{F}_{4}$ and $\mathrm{F}_{5}$ generations, progeny rows (families) are discarded when they are found to be susceptible to frogeye (Cercospora) leaf spot or bacterial pustule, or if they are of poor seed color or plant type. Single plant selections to establish homozygous lines are done at $F_{5}$ or $F_{6}$ generation during the main growing season. Seeds of selected individual plants are then multiplied during the off-season. At this stage lines are screened for pod shattering in the laboratory, seed size (10-13 g per 100 seeds), and uniform cream seed color. Progeny rows that passed the screening procedure are harvested in bulk grouped by maturity and were promoted to preliminary variety trials. The maturity groups in IITA trials are early (less than 100 days), medium (101 - 110 days) and late (more than 110 days).

Twenty-five to 30 superior lines are normally tested under preliminary variety trials at two to three locations in three replications for one year. Better performing lines for key traits are promoted to the advanced variety trial and the rest are discarded. In the advanced variety trial, lines are evaluated in at least three locations in four replications per country. The best lines from the advanced variety trial are distributed to collaborators mainly in Africa in the form of international trials. The purpose of the international trials are to test adaptation of elite soybean lines in different countries under diverse environmental conditions so that breeders from different national programs are able to compare their local varieties with the new lines and eventually release new varieties from IITA's lines. Moreover, it helps national breeders to access new germplasm from IITA for their breeding programs. Within Nigeria, these superior lines are promoted to the National Soybean Variety Trials, which are part of the Nationally Coordinated Research Projects on soybean. While evaluating lines, all the crop management practices are similar to farmer's condition. Starter fertilizer is incorporated into the soil before planting and the rate used is $100 \mathrm{~kg} \mathrm{ha}^{-1}$ NPK (15-15-15) and $50 \mathrm{~kg} \mathrm{ha}^{-1}$ single super phosphate. No fungicides, insecticides or Rhizobium inoculants are used and weeds are controlled using herbicides and hoe as needed. 


\section{Breeding lines developed for promiscuous nodulation}

Over 2000 soybean crosses have been made since the late 1980s to select desirable segregants. Since late 1980 s at least 66,220 segregating populations have been raised and more than 400 trials have been carried out. During the same period more than 20,000 soybean lines have been tested by IITA breeders in at least 20 locations in western and southern Africa. Large number of early, medium and late maturing promiscuous breeding lines has been developed over the past three decades. IITA's effort in breeding promiscuous early maturing soybeans has resulted in the development of 35 promising lines until 2006. These superior breeding lines are available for on-farm testing and release by national programs. In these materials maturity ranged from 91-107 days on the average (Table 3). Average grain yield ranged from $1257 \mathrm{~kg} \mathrm{ha}^{-1}$ for TGx 1826-5E in 1997 to $2959 \mathrm{~kg} \mathrm{ha}^{-1}$ for TGx 1895-4F in 2000. Percent increase of grain yield in these promising lines as compared to checks in the respective years ranged from 12-65\%. Fodder yield ranged from $1548 \mathrm{~kg} \mathrm{ha}^{-1}$ for TGx $1805-8 \mathrm{~F}$ to $3208 \mathrm{~kg} \mathrm{ha}^{-1}$ for TGx 1925-1F in 2004. It is to be noted that the average yield of $1257-1271 \mathrm{~kg} \mathrm{ha}^{-1}$ for grain yield in 1997 and 1998 were realized without any fertilizer or other input. However, in the years 1990 and 1999-2006 a basal fertilizer of $100 \mathrm{~kg}$ $\mathrm{ha}^{-1}$ of 15:15:15 NPK plus $50 \mathrm{~kg} \mathrm{ha}^{-1}$ triple super phosphate were applied to attain those yields by the promiscuous lines.

Twenty five promising and medium maturing lines were developed from 1988-2006 for further utilization by the national programs. Average maturity date ranged from 100-120 days and grain yield ranged from $1275-2396 \mathrm{~kg} \mathrm{ha}^{-1}$ (Table 4). Similarly, average fodder yield ranged from 1194-2882 kg ha-1 for these lines. Percent grain yield increase of these lines over their respective checks in different years ranged from $11-107 \%$. As indicated for the early lines, trials in 1997 did not receive fertilizers and as a result yields were 1275-1424 kg ha-1 $^{-1}$ which is much higher than farmer's yields. Breeding for late maturity has resulted in the development of 20 promising lines from 1989 - 2005 (Table 5). These lines exceeded the respective checks in grain yield in different years by $9-63 \%$. Both grain and fodder yields were low in 1997 and 1998 since in those years breeders did not use starter fertilizer. These promising lines matured in 107-123 days on the average under West African condition. Grain and fodder yields were in the range of $1104-2500 \mathrm{~kg} \mathrm{ha}^{-1}$ and $1197-3000 \mathrm{~kg} \mathrm{ha}^{-1}$, respectively. Lower values were from the unfertilized years. These promiscuous lines are of significant value for agro-ecologies with long growth period and high rainfall. The breeding program also attempted to specifically develop desirable materials for drier Sudan savanna zone of Nigeria. That effort resulted in the development of 11 superior lines for environments similar to Kano. The lines matured in 86-101 days and their grain yields ranged from 1501-2365 kg ha-1. Fodder yields also ranged from 1542-2333 kg ha-1. Grain yield advantages over checks were $15-77 \%$.

\section{Promiscuous varieties released}

A total of 21 IITA bred tropical soybean varieties have been released in Africa (Table 6). Most of these varieties were released in Nigeria. Some were released by the national agricultural research systems (NARS) of Ghana, Benin, Togo, Democratic Republic Congo, Uganda and Ethiopia. In terms of maturity groups, seven varieties each were released from the early, medium and late, respectively. Grain yields ranged from $1-2.1$ tha-1 in the early maturing varieties depending on locations. In medium maturing varieties grain yields ranged from $1-2.7 \mathrm{t} \mathrm{ha}^{-1}$. In the case of late maturing varieties grain yields ranged from 


\begin{tabular}{|c|c|c|c|c|}
\hline Year & Line & $\begin{array}{l}\text { Maturity } \\
\text { date }\end{array}$ & $\begin{array}{c}\text { Grain yield } \\
\left(\mathrm{kg} \mathrm{ha}^{-1}\right)\end{array}$ & $\begin{array}{l}\text { Fodder yield } \\
\quad\left(\mathrm{kg} \mathrm{ha}^{-1}\right)\end{array}$ \\
\hline 1990 & TGx 1660-15F & $96-99$ & $1896-2250$ & 1896 \\
\hline 1997 & TGx 1826-5E & $97-103$ & $1100-1670$ & 2222 \\
\hline 1998 & TGx 1878-30E & $94-113$ & 1089-1714 & $1779-1958$ \\
\hline 1999 & TGx 1805-8F & $85-95$ & $687-2280$ & $1021-2444$ \\
\hline 1999 & TGx 1830-20E & $85-98$ & $648-2365$ & $1500-2500$ \\
\hline 1999 & TGx 1831-32E & $88-100$ & $875-1569$ & $979-1806$ \\
\hline 1999 & TGx 1871-12E & $91-97$ & 1109-2204 & 1896-2444 \\
\hline 1999 & TGx 1835-10E & 89-92 & $1550-2494$ & $1562-3055$ \\
\hline 1999 & TGx 1740-2F & $92-96$ & $1761-2232$ & $1896-2278$ \\
\hline 1999 & TGx 1876-4E & 89-99 & $1023-1674$ & 1146-1889 \\
\hline 1999 & TGx 1880-3E & $98-119$ & 963-1922 & $938-2167$ \\
\hline 1999 & TGx 1842-1E & 94-101 & $601-1501$ & $1458-2194$ \\
\hline 1999 & TGx 1834-1E & $92-100$ & 835-1842 & 1406-2194 \\
\hline 2000 & TGx 1895-4F & $90-99$ & $1068-4389$ & $2375-3583$ \\
\hline 2000 & TGx 1895-49F & 93-104 & $1251-2639$ & $1926-3417$ \\
\hline 2000 & TGx 1895-33F & $102-104$ & $962-3117$ & $1917-4037$ \\
\hline 2002 & TGx 1903-3F & $98-102$ & 1423-2309 & $1667-1875$ \\
\hline 2002 & TGx 1905-5F & $96-101$ & $1518-1935$ & $1417-2125$ \\
\hline 2003 & TGx 1903-8F & $102-104$ & 1534-1924 & $1000-2666$ \\
\hline 2003 & TGx 1908-1F & $103-110$ & $1565-1847$ & $1958-2353$ \\
\hline 2004 & TGx 1925-1F & $103-110$ & $1468-2224$ & 2958-3375 \\
\hline 2004 & TGx 1919-1F & $101-108$ & $1594-2148$ & $2500-2833$ \\
\hline 2004 & TGx 1904-2F & $95-103$ & $1540-1953$ & $2437-2667$ \\
\hline 2004 & TGx 1903-7F & $96-104$ & $1468-2021$ & $1833-2396$ \\
\hline 2006 & TGx 1954-1F & 103-109 & $1771-2811$ & $1893-3167$ \\
\hline 2006 & TGx 1977-4F & $102-106$ & $1041-3374$ & $1584-2751$ \\
\hline 2006 & TGx 1951-4F & $101-107$ & 1503-2719 & $1338-3084$ \\
\hline 2006 & TGx 1977-2F & $97-102$ & $904-3026$ & $1479-2667$ \\
\hline 2006 & TGx 1935-3F & 79-105 & $1039-3052$ & $1792-3042$ \\
\hline 2006 & TGx 1971-1F & $100-108$ & $1576-2648$ & $1625-2459$ \\
\hline 2006 & TGx 1965-7F & $100-102$ & $1199-2913$ & $1167-2375$ \\
\hline 2006 & TGx 1972-1F & $99-105$ & $1437-2750$ & 1417-2209 \\
\hline 2006 & TGx 1951-3F & $100-105$ & $1734-2460$ & $1500-2726$ \\
\hline 2006 & TGx 1945-1F & $102-111$ & 1209-2584 & 1959-3334 \\
\hline 2006 & TGx 1978-3F & 100-105 & $1060-2666$ & $1084-2125$ \\
\hline
\end{tabular}

Table 3. Ranges of maturity, grain and fodder yields of superior early maturing promiscuous soybean lines developed by IITA in the Guinea savanna of Nigeria from 1999 2006. Note: Lines identified in 1990 and from 1999-2005 received $100 \mathrm{~kg}^{-1} \mathrm{~h}^{-1}$ of 15:15:15 NPK plus $50 \mathrm{~kg} \mathrm{ha}^{-1}$ triple super phosphate (TSP) whilst those identified from 1997-1998 did not receive fertilizer. In all cases no rhizobium inoculants were used. 


\begin{tabular}{|c|c|c|c|c|}
\hline Year & Line & $\begin{array}{l}\text { Maturity } \\
\text { date }\end{array}$ & $\begin{array}{l}\text { Grain yield } \\
\left(\mathrm{kg} \mathrm{ha}^{-1}\right)\end{array}$ & $\begin{array}{l}\text { Fodder yield } \\
\quad\left(\mathrm{kg} \mathrm{ha}^{-1}\right)\end{array}$ \\
\hline 1990 & TGx 1489-1D & $101-113$ & $2041-2718$ & - \\
\hline 1990 & TGx 1440-1E & $115-122$ & $2247-2484$ & - \\
\hline 1990 & TGx 1649-9F & $110-120$ & $1590-2382$ & - \\
\hline 1997 & TGx 1837-2E & $105-122$ & 799-2004 & $1667-2000$ \\
\hline 1999 & TGx 1805-31F & $104-108$ & $1257-2048$ & 2062-2944 \\
\hline 1999 & TGx 1873-16E & $104-115$ & $1290-1938$ & $1750-2833$ \\
\hline 2000 & TGx 1894-3F & $101-112$ & $1192-3120$ & $2396-3458$ \\
\hline 2000 & TGx 1869-31E & $96-106$ & $1125-2955$ & $1935-3292$ \\
\hline 2000 & TGx 1888-15F & $96-109$ & $1252-3152$ & $1833-3125$ \\
\hline 2003 & TGx 1910-13F & $103-116$ & $1129-2001$ & $2312-3124$ \\
\hline 2003 & TGx 1904-3F & $104-114$ & $1324-2265$ & $2312-2636$ \\
\hline 2003 & TGx 1904-6F & $104-114$ & $1213-2248$ & $1624-2457$ \\
\hline 2003 & TGx 1905-2F & $105-118$ & $568-2137$ & $1687-2353$ \\
\hline 2004 & TGx 1908-3F & $102-114$ & $1295-2411$ & $2625-3187$ \\
\hline 2004 & TGx $1927-5 \mathrm{~F}$ & $103-114$ & $1195-2269$ & $2417-3125$ \\
\hline 2004 & TGx 1926-4F & $101-116$ & $981-2139$ & $2417-3021$ \\
\hline 2004 & TGx 1908-8F & $104-113$ & $1010-2169$ & $2333-3000$ \\
\hline 2004 & TGx 1910-10F & $105-115$ & $937-2637$ & $2458-3250$ \\
\hline 2006 & TGx 1956-1F & $103-110$ & $1301-2878$ & $1709-3042$ \\
\hline 2006 & TGx 1963-3F & $105-109$ & $1452-2746$ & $1917-2521$ \\
\hline 2006 & TGx 1961-1F & $102-105$ & $1242-2877$ & 1709-2709 \\
\hline 2006 & TGx 1965-5F & $102-107$ & $956-3124$ & $1581-2626$ \\
\hline 2006 & TGx 1937-1F & $105-111$ & $1364-2557$ & $938-2876$ \\
\hline 2006 & TGx 1955-4F & $105-110$ & $1373-2634$ & $1584-2626$ \\
\hline 2006 & TGx 1954-4F & $106-113$ & $1468-2493$ & $1750-3042$ \\
\hline
\end{tabular}

Table 4. Ranges of maturity, grain and fodder yields of medium maturing promiscuous soybean lines developed by IITA in the Guinea savanna of Nigeria. Lines identified from 1988-1989 received $100 \mathrm{~kg} \mathrm{ha}^{-1}$ of 15:15:15 NPK plus $200 \mathrm{~kg}^{-1} \mathrm{a}^{-1}$ triple super phosphate (TSP); Lines identified from 1990-1991 and from 1999-2005 received $100 \mathrm{~kg}^{-1} \mathrm{~h}^{-1}$ of 15:15:15 NPK plus $50 \mathrm{~kg} \mathrm{ha}^{-1}$ TSP whilst those identified from 1997 did not receive fertilizer. In all cases no rhizobium inoculants were used.

1.3 - $2.3 \mathrm{t} \mathrm{ha}^{-1}$. These yields were achieved through natural nodulation and only starter fertilizers were applied. In addition to grain yield and promiscuous nodulation, several other traits were incorporated into these varieties. Some of them are fodder yield, seed longevity, resistance to shattering and lodging, suitability for processed products such as soymilk, resistance to major foliar diseases such as bacterial blight and pustule, frogeye leaf spot and tolerance to rust in recently released varieties. 


\begin{tabular}{clrrr}
\hline Year & \multicolumn{1}{c}{ Line } & $\begin{array}{c}\text { Maturity } \\
\text { date }\end{array}$ & $\begin{array}{c}\text { Grain yield } \\
\left(\mathrm{kg} \mathrm{ha}^{-1}\right)\end{array}$ & $\begin{array}{c}\text { Fodder yield } \\
\left(\mathrm{kg} \mathrm{ha}^{-1}\right)\end{array}$ \\
\hline 1989 & TGx 1410-1D & $120-121$ & $2468-2834$ & - \\
1989 & TGx 1483-3D & $113-115$ & $1981-2692$ & - \\
1989 & TGx 1440-1E & $116-125$ & $666-4365$ & - \\
1989 & TGx 1448-1E & $115-125$ & $1074-3768$ & - \\
1990 & TGx 1448-2E & $115-117$ & $2403-2458$ & - \\
1990 & TGx 1489-1D & $101-113$ & $2041-2718$ & - \\
1997 & TGx 1843-35E & $119-131$ & $688-1540$ & $1792-1875$ \\
1998 & TGx 1828-4E & $106-125$ & $1191-1236$ & $1019-1375$ \\
1999 & TGx 1844-4E & $120-125$ & $1800-2500$ & $2200-3000$ \\
1999 & TGx 1844-18E & $113-115$ & $803-1718$ & $1542-2639$ \\
2002 & TGx 1905-5F & $116-116$ & $1629-3048$ & $2313-2792$ \\
2003 & TGx 1910-2F & $117-123$ & $2289-2521$ & $2166-2374$ \\
2003 & TGx 1910-8F & $104-119$ & $1848-2870$ & $2624-3374$ \\
2003 & TGx 1910-3F & $119-127$ & $2157-2452$ & $2416-3249$ \\
2003 & TGx 1910-6F & $116-127$ & $2080-2416$ & $2541-2832$ \\
2003 & TGx 1910-14F & $112-123$ & $2035-2433$ & $2353-2916$ \\
2004 & TGx 1927-1F & $115-118$ & $1847-2127$ & $2453-2500$ \\
2004 & TGx 1910-11F & $110-115$ & $1285-1825$ & $1542-2625$ \\
2004 & TGx 1924-2F & $114-117$ & $1757-1802$ & $2042-2875$ \\
2005 & TGx 1949-7F & $113-121$ & $1417-2257$ & $2042-2250$ \\
\hline
\end{tabular}

Table 5. Ranges of maturity, grain and fodder yields of late maturing promiscuous soybean lines developed by IITA in the Guinea savanna of West Africa.

\section{Promiscuous soybeans in cropping systems of the savanna}

The role of promiscuous soybeans for soil health and effect on productivity of subsequent cereal crops after soybean has been investigated in a greater detail by IITA scientists in the past two decades. The study carried out by Carsky et al. (1997) estimated the value of residual soybean nitrogen on subsequent maize grain yield under the prevailed situation of soybean residue removal at 10 sites in the Guinea savanna of Nigeria using one early (TGx 1456-2E) and one medium maturing (TGx 1660-19F) varieties of soybean. These researchers reported that the yield increase following the medium duration soybean variety was similar to that from $40 \mathrm{~kg} \mathrm{ha}^{-1}$ nitrogen applied four weeks after planting to maize preceded by maize. Their study also revealed that the total nitrogen in the $0-10 \mathrm{~cm}$ depth of the previous TGx $1660-19 \mathrm{~F}$ plots $(0.063 \%)$ was significantly greater $(\mathrm{p}<0.05)$ than in the previous maize plots $(0.058 \%)$ considering all sites of the study. Carsky et al. (1997) concluded that the effect of previous soybean crop on maize grain yield was due to residual nitrogen availability either from the roots, fallen plant parts of soybean or nitrate-sparing effect. Nitrogen fixation and nitrogen contribution by different promiscuous nodulating soybean lines were further studied in the southern Guinea savanna of Nigeria by Sanginga et al. (1997). These workers reported that nitrogen derived from the atmosphere and nitrogen derived from the soil were the major sources of nitrogen accounting for 84 and $75 \mathrm{~kg} \mathrm{~N} \mathrm{ha}^{-1}$ or $46 \%$ and $43 \%$, respectively, of the plant total nitrogen. They observed a great variation among soybean genotypes in that a late maturing genotype, TGx 1660-19F, derived on the average $126 \mathrm{~kg} \mathrm{~N}$ 
ha-1 (52\% of plant total nitrogen) from $\mathrm{N}_{2}$ fixation as compared to the early maturing line IAC 100 with $37 \mathrm{~kg} \mathrm{~N}^{-1}$ (38\%). Sanginga et al. (1997) estimated a net contribution of $18 \mathrm{~kg}$ $\mathrm{N}$ ha-1 to soil on the average after grain removal and it ranged from -8 to $43 \mathrm{~kg} \mathrm{~N} \mathrm{ha-1}$ depending on the soybean line grown.

Further study by Sanginga et al. (2002) substantiated the beneficial effect of soybean to maize in that 1.2 - 2.3-fold increase in maize yield was obtained when grown after soybean as compared to maize after maize. On-farm study in southern Guinea savanna using TGx 1456-2E and TGx 1660-19F indicated that these lines fixed 39-54\% of their total nitrogen requirement that amounted to $56-70 \mathrm{~kg} \mathrm{~N}^{-1}$ in TGx $1456-2 \mathrm{E}$ and $51-78 \mathrm{~kg} \mathrm{~N}^{-1}$ in TGx 1660-19F (Osunde et al., 2003). A maize grain yield of $3 \mathrm{t} \mathrm{ha}^{-1}$ was reported by these workers indicating the tremendous contribution from a 2-year soybean rotation. They recommended growing of promiscuous soybeans in rotation with maize even without the residues of soybean being returned to the farm land. Overall, studies indicated that under the Guinea savanna condition of Nigeria, promiscuous lines of soybean derive $46 \%$ of their plant total N (85 kg N ha-1) from the atmosphere and the balance $43 \%\left(75 \mathrm{~kg} \mathrm{~N} \mathrm{ha}^{-1}\right)$ from the soil. Thus, Sanginga (2003) suggested that breeding for higher nitrogen derived from the atmosphere lines should continue along with the development of efficient Bradyrhizobium strains as inoculants.

\section{Dual-purpose soybean lines}

Most of the IITA promiscuous soybean varieties and lines have been bred for dual-purpose to fit into the mixed farming system of the savanna. For some of the varieties specific studies were carried out to identify their feed value. From all maturity groups of soybean, lines were identified with high grain and stover yields and good stover quality assessed based on crude protein, neutral detergent fiber and dry matter digestibility (IITA, 2000). Lines that possess these qualities from the early maturity group are TGx 1878-30E, TGx 1880-3E, TGx 1019-2EB, and TGx 1871-12E and from medium maturity group they are TGx 1873-6E, TGx 1869-14E, TGx 1880-15E, and Samsoy-1. From the late maturity group TGx 1869-13E, TGx 1440-1E, TGx 1871-6E, and TGx 1872-23E are identified as the best lines.

\section{Breeding promiscuous soybeans for low phosphorus tolerance}

Phosphorus is a limiting factor to soybean growth as the process of nitrogen fixation needs phosphorus. Ogoke et al. (2001) studied the role of phosphorus in enhancing soybean residue contribution to soil fertility. They reported that litter residue increased by $42-46 \%$ with phosphorus application as compared to no phosphorus treatment. Further work of Ogoke et al. (2003) demonstrated that application of fertilizer phosphorus was justified and necessary in soils where phosphorus levels were below $7 \mathrm{mg} \mathrm{kg}^{-1}$ in the savanna since soybean nitrogen content increased as a result of phosphorus application. They reported that total nitrogen content in soybean was increased by $40-47 \%$ when phosphorus was applied. A study was carried out for two cropping seasons (2002 and 2003) at Mokwa and Zaria in Nigeria to see the response of four soybean varieties to different levels of phosphorus. Two levels of phosphorus $\left(0 \mathrm{~kg} \mathrm{ha}^{-1}\right.$ and $\left.30 \mathrm{~kg} \mathrm{ha}^{-1}\right)$ and four varieties (M 351, TGx 1485-1D, TGx 1844-18E, and TGx 1871-12E) were evaluated in a split plot design with three replications (IITA, 2003). Data on grain yield, fodder, number of nodules, and plant height were recorded. The results showed that grain yield, fodder yield, number of nodules, 
and plant height were higher for the new varieties (TGx 1844-18E and TGx 1871-12E) than the old ones (M 351 and TGx 1485-1D) both at 0 and $30 \mathrm{~kg} \mathrm{ha}^{-1}$ of phosphorus application. The average grain yield of the new varieties was $58 \%$ higher than the old varieties at $0 \mathrm{~kg} \mathrm{ha}^{-}$ ${ }^{1}$ and $65 \%$ higher at $30 \mathrm{~kg} \mathrm{ha}^{-1}$ of phosphorus. Increases in grain, fodder, number of nodules and plant height were obtained due to $\mathrm{P}$ application.

\begin{tabular}{|c|c|c|c|c|}
\hline Year & Variety & $\begin{array}{c}\text { Maturity } \\
\text { class and } \\
\text { date }^{1}\end{array}$ & $\begin{array}{l}\text { Grain } \\
\text { yield } \\
\text { (t/ha) }\end{array}$ & $\begin{array}{l}\text { Releasing } \\
\text { Country }\end{array}$ \\
\hline 1989 & TGx 297-10F & $108-118(\mathrm{M})$ & $2.0-2.1$ & Ghana \\
\hline 1989 & TGx 297-192C & $105-112(\mathrm{M})$ & $1.4-1.8$ & Ghana \\
\hline 1989 & TGx 306-036C & $118-125(\mathrm{~L})$ & $1.5-2.0$ & Ghana, Nigeria \\
\hline 1989 & TGx 888-49C & $121-125(\mathrm{~L})$ & 1.4 & Ghana \\
\hline 1989 & TGx 923-2E & $118-122(\mathrm{~L})$ & $1.5-2.0$ & Nigeria \\
\hline 1989 & TGx 536-02D & $100-110(\mathrm{M})$ & $1.0-1.5$ & Ghana, Nigeria \\
\hline 1989 & TGx 813-6D & $105-110(\mathrm{M})$ & $1.5-2.0$ & Ghana \\
\hline 1989 & TGx 814-76D & $110-117(\mathrm{~L})$ & $1.3-1.8$ & DR Congo \\
\hline 1989 & TGx 849-294D & $97-103(\mathrm{E})$ & $1.2-1.8$ & DR Congo \\
\hline 1991 & TGx 849-313D & $109-115(\mathrm{M})$ & $1.4-1.8$ & Nigeria \\
\hline 1991 & TGx 1019-2EN & $98-106(\mathrm{E})$ & $1.5-1.8$ & Nigeria \\
\hline 1991 & TGx 1019-2EB & $105-110(\mathrm{M})$ & $1.5-2.0$ & Nigeria \\
\hline 1992 & TGx 1440-1E & $115-120(\mathrm{~L})$ & $1.7-2.2$ & $\begin{array}{l}\text { Nigeria (1992); Benin and Togo } \\
\text { (1998) }\end{array}$ \\
\hline 1992 & TGx 1448-2E & $115-120(\mathrm{~L})$ & $1.7-2.3$ & $\begin{array}{l}\text { Nigeria (1992); Benin, Ghana } \\
\text { and Togo (1998) }\end{array}$ \\
\hline 1998 & TGx 1485-1D & 85-95 (E) & $1.0-1.5$ & $\begin{array}{l}\text { Nigeria (1992); Benin and Togo } \\
\text { (1998) }\end{array}$ \\
\hline 1998 & TGx $1740-2 \mathrm{~F}$ & 95-100 (E) & $1.0-1.5$ & $\begin{array}{l}\text { Nigeria (1992); Benin and Togo } \\
\text { (1998) }\end{array}$ \\
\hline 2005 & TGx 1830-20E & $90-93(\mathrm{E})$ & 2.1 & Ghana (2005) \\
\hline 2005 & TGx 1904-5F & 92-97 (E) & - & Ghana (2005) \\
\hline $\begin{array}{l}2004 \\
2009\end{array}$ & TGx 1835-10E & $90-95(E)$ & 2.0 & Uganda (2004), Nigeria (2009) \\
\hline 2007 & TGx 1892-10E & $121(\mathrm{~L})$ & 1.5 & Ethiopia \\
\hline 2009 & TGx 1904-6F & $101-108(\mathrm{M})$ & $2.5-2.7$ & Nigeria \\
\hline
\end{tabular}

Table 6. Promiscuous soybean varieties developed by IITA and officially released by

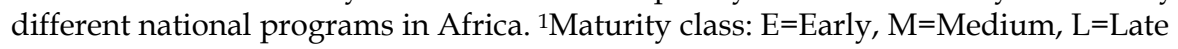

\section{Breeding promiscuous soybeans for shattering resistance}

Pod shattering resistance is another trait considered for improving promiscuous soybeans at IITA. Pod shattering is the opening of pods along both dorsal and ventral sutures of the soybean pod (Tukamuhabwa et al., 2000). A seed loss of $50-100 \%$ can occur in susceptible varieties as a result of delayed harvesting after physiological maturity (IITA, 1986). Genetic studies revealed that pod shattering in soybean is under control of two pairs of genes and is partially dominant over resistance (Tukamuhabwa et al., 2000). This trait is highly heritable 
with narrow sense heritability values of 0.70-0.79 (Tukamuhabwa et al., 2000; 2002). These findings indicated that pod shattering resistance can be improved with simple breeding procedures. Therefore when line evaluation trials are being conducted in the field, observation is made for shattering by visual rating of border rows of plots two weeks after harvesting. Laboratory method of screening for shattering resistance has also been followed since 1984. In this method 25 light brown pods are collected from each plot in paper bags and are put on a shelf and stored at room temperature for 10-20 days (Dashiell et al., 1987). Samples are then put in an oven set at room temperature, and each day the temperature in the oven is increased by $5^{\circ} \mathrm{C}$ and the number of shattered pods is counted. The assumption with this method is that samples that remained in the oven for a longer period of time without shattering had a good resistance (IITA, 1985). All IITA developed varieties and lines have some degree of pod shattering resistance.

\section{Promiscuous soybean lines that reduce Striga hermonthica seed bank}

Trials in 1996 and 1997 showed less number of Striga emergence on maize plot previously used for growing soybean, and grain and stover yields of maize were higher following soybean as compared to following sorghum (IITA, 1997). This observation prompted further work on the role of soybean in Striga control. Study was carried out on the screening of soybean lines for their efficiency in suicidal germination of Striga hermonthica seeds. Germination of Striga seeds stimulated in vitro by 159 lines of soybean varied with both the populations of the parasite and the soybean lines (IITA, 2003). Percentages varied from 0.0 to 31.2 (Gezawa population), from 0.1 to 36.0 (Mokwa population), and from 0.2 to 13.1 (Zaria population). The highest germination percentage among the Zaria population (13.1) was only $36 \%$ and $42 \%$ of those among the Mokwa and Gezawa populations. The germination percentage induced by the top 20 lines ranged from 6.6 (TGx 1805-8F) to 31.2 (TGx 1844-18E) for the Gezawa population, from 5.1 (TGx 1912-7F) to 13.1 (TGx 1924-4F) for the Zaria population, and from 12.5 (TGx 1908-1F) to 36.0 (TGx 1910-16F) for the Mokwa population. Further work involved testing the effect of a soybean crop as compared to sorghum as control on S. hermonthica parasitism in a subsequent maize crop and this study also assessed the effects of increasing soybean plant density and phosphorus fertilizer application on Striga reduction (Carsky et al., 2000). Application of phosphorus to soybean at higher soybean densities resulted in higher root length density, lower emerged $S$. hermonthica on maize and significantly higher maize yield (Carsky et al., 2000). These investigators reported that soybean rotation increased maize yield by $90 \%$ and suggested that the use of an efficacious soybean cultivar reduces Striga parasitism on a succeeding maize crop and that the effect is increased by application of phosphorus to the soybean.

\section{Genetic gains in breeding for promiscuous soybeans}

Knowledge on the genetics of promiscuity is essential to develop a naturally nodulating soybean varieties. From preliminary work at IITA, Kueneman et al. (1984) suggested that promiscuity in soybean is a heritable trait as they observed a large number of well nodulating plants in early generation from a cross of promiscuous and specific types of soybean genotypes. Gwata et al. (2004) carried out a study on the genetics of promiscuous nodulation using nodule dry weight and leaf color score as a measure of nitrogen fixation effectiveness in six basic generations produced from two contrasting parents (promiscuous 
and non-promiscuous). For nodule dry weight trait, non-promiscuity was reported to be partially dominant controlled by four loci and for leaf color score non-promiscuity was reported to be completely dominant and it was controlled by two loci (Gwata et al., 2004). These authors suggested that leaf color (deep greenness) score as a reliable trait to assess nitrogen fixation in soybean as it represented the total effectiveness of nodulation to provide nitrogen to the plant. Further study on the inheritance of promiscuous nodulation in $\mathrm{F}_{2}$ segregation pattern revealed that two alleles at each of two independent loci with a dominant gene action and function controlled promiscuous nodulation (Gwata et al., 2005). These authors identified that green $\left(\mathrm{N}_{2}\right.$ fixing) genotypes were double recessive and any individual possessing at least one dominant allele at either locus would be nonpromiscuous. Gwata et al. (2005) proposed gene 1 and gene 2 for the two alleles that control promiscuous nodulation. These authors also suggested that the leaf color (green) method was a rapid and least expensive procedure as compared to other methods like acetylene reduction or xylem ureide assay. They argued that the leaf score method is adequate in plant breeding programs concerned with rapid screening methods for promiscuous nodulation under nitrogen-depleted growth conditions.

Since promiscuous nodulation is a heritable trait, IITA breeders have been able to recover lines with good agronomic characteristics and the ability to nodulate well with indigenous rhizobia by crossing promiscuous germplasm with varieties from the USA that have got superior agronomic traits (Kuneman et al., 1984). IITA breeders have assessed the genetic gain made in breeding early, medium and late maturing promiscuous soybeans in tropical Africa. The average rate of increase per year per release period of 1980 to 1996 for grain yield was $24.2 \mathrm{~kg} \mathrm{ha}^{-1}$, which amounted to a genetic gain of $2.2 \%$ (Tefera et al., 2009). In the

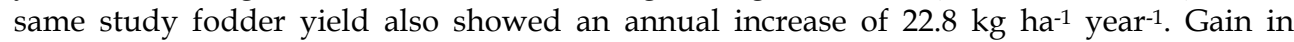
improving natural nodulation was $1.72 \%$ per year (Tefera et al., 2009). Similarly in medium maturing varieties of soybean the annual rate of progress against year of release was found to be $23.6 \mathrm{~kg} \mathrm{ha}^{-1}$ or $1.99 \%$ (Tefera et al., 2010). For late maturing varieties, the annual rate of breeding progress during 16 years of improvement period was $22.2 \mathrm{~kg} \mathrm{ha}^{-1}$ or $1.42 \%$ (Tefera et al., 2010).

\section{Future direction of breeding for promiscuity}

Promiscuous varieties and lines were developed at IITA to enhance biological nitrogen fixation (BNF) of soybeans so that small-scale farmers do not need to apply nitrogen fertilizer. In the past three decades this approach of breeding soybeans has been implemented vigorously and almost all varieties and lines at IITA have promiscuity character. The breeding program needs to select for enhanced promiscuity trait while developing varieties resistant to biotic and abiotic stresses. It is essential to select plants with high biological nitrogen fixation capacity in early segregating generations preferably on soils with low nitrogen. Selection at early stage will help to maximize gains in breeding for promiscuity trait. While handling large number of segregating populations easy to measure traits as indicator of biological nitrogen fixation should be used as suggested by Gwata et al. (2005).

In addition to breeding for promiscuous nodulation, effort should be made to develop adapted high yielding specific varieties with specific strains of Bradyrhizobium. The use of effective inoculant strains could enhance the biological nitrogen fixation capacity of promiscuous genotypes. Generally, the identification of soybean cultivars with a high 
capacity for biological nitrogen fixation is important when recommending cultivars to farmers, as well as determining cultivars for use as parental genotypes in breeding programs (Hungria and Bohrer, 2000). Several investigators have demonstrated that breeding soybean for enhanced $\mathrm{N}_{2}$ fixation can be successful (Hungria and Bohrer, 2000; Alves et al., 2003). For profitable and sustainable soybean production a continuous and coordinated selection of the most effective host genotype and rhizobial strain is essential. There is a great potential to enhance $\mathrm{N}_{2}$ fixation in soybean through breeding genotypes with enhanced capacity to interact with Rhizobium bacteria. Improved $\mathrm{N}_{2}$ fixing in soybean may result from manipulating both the host genotype and rhizobia. Hence, the breeding program will employ selection of soybean lines under inoculation for enhanced BNF.

\section{Conclusion}

Soybean is emerging as an important feed, food as well as raw material for producing highquality protein products in Africa. In the past five years, soybean area has been increasing at an average of $5 \%$ per year whilst total production has been increasing at a rate of $7 \%$ per year in Africa. Such an increase has not been sufficient to satisfy the demand for soybean in the continent. Hence, the development of adapted and high yielding soybean varieties is necessary. IITA has been leading this effort in the past several decades by way of developing promiscuous varieties and through the promotion of soybean processing and utilization in the continent. A total of 21 IITA bred promiscuous tropical soybean varieties have been released in different countries of Africa. These varieties are easily grown by farmers without requiring specific inoculants or nitrogen fertilizers and thus an appropriate technology for small-scale farmers. These varieties give up to 2.7 tons/ha grain yield, much higher than the 1 ton/ha average yield for Africa, in addition to the high fodder yield for livestock feed. Breeding for promiscuity character has been a success at IITA. Genetic gain in breeding early, medium and late maturing varieties has been $2.2 \%, 1.9 \%$ and $1.4 \%$, respectively. Efforts will be made to avail these superior promiscuous genotypes to different countries in Africa to test their adaptation and use them as variety per se or consider them as parental materials in their soybean improvement work. In IITA the breeding program will pursue to further enhance the biological nitrogen fixation capacity of new breeding lines through the promiscuity approach as well as matching genotypes with effective inoculant strains.

\section{References}

Asafo-Adeji, B. \& Adekunle, A. A. (2001). Characteristics of some released IITA soybean varieties and promising advanced breeding lines. International Institute of Tropical Agriculture, Ibadan, Nigeria.

Alves, B. J. R.; Boddy, R. M. \& Urquiaga, S. (2003). The success of BNF in soybean in Brazil. Plant and Soil, 252, 1, (May 2003) 1-9, ISSN: 0032 - 079X.

Carsky, R. J.; Abaidoo, R.; Dashiell, K. \& Sanginga, N. (1997). Effect of soybean on subsequent maize grain yield in the Guinea savanna zone of West Africa. African Crop Science Journal, 5, 1 (1997) 31-38, ISSN 1021 - 9730.

Carsky, R. J.; Berner, D. K.; Oyewwole, B. D.; Dashiell, K. \& Schulz, S. (2000). Reduction of Striga hermonthica parasitism on maize using soybean rotation. International Journal of Pest Management, 46, 2, (April 2000) 115-120, ISSN: 1366 - 5863. 
Dashiell, K. E.; Bello, L. L. \& Root, W. R. (1987). Breeding soybeans for the tropics, In: Soybeans for the Tropics: Research, Production and Utilization, Singh, S.R.; Rachie, K. O. \& Dashiell, K. E., (Ed.), 3-16, John Wiley \& Sons Ltd, New York, ISBN 0471914193.

Flaskerud, G. (2003). Brazil's soybean production and impact. North Dakota State University, Extension Service, Fargo, North Dakota. Avaialble at: http:// www.ag.ndsu.nodak.edu.

Giller, K. E. \& Dashiell, K. E. (2006). Glycine max (L.) Merr. In: Plant Resources of Tropical Africa 1. Cereals and pulses, Brink, M. \& Belay, G. (Ed.), 76-82, PROTA Foundation, Wageningen, Netherlands/Backhuys Publishers, Leiden, Netherlands/CTA, Wageningen, Netherlands.

Gwata, E. T.; Wofford, D. S.; Pfahler, P. L. \& Boote, K. J. (2004). Genetics of promiscuous nodulation in soybean: Nodule dry weight and leaf color score. Journal of Heredity, 95, 2, (March 2004) 154-157, ISSN: 0022 - 1503.

Gwata, E. T.; Wofford, D. S.; Boote, K. J.; Blount, A. R. \& Pfahler, P. L. (2005). Inheritance of promiscuous nodulation in soybean. Crop Science, 45, 2, (March - April 2005) 635638, ISSN: 0011 - 183X.

Hungria, M. \& Bohrer, T. R. J. (2000). Variability of nodulation and dinitrogen fixation capacity among soybean cultivars. Biology and Fertility of Soils, 31, 1, (April 2000) 4552, ISSN: 0178 - 2762.

IITA (1985). Annual report. Ibadan, Nigeria.

IITA (1986). Annual report. Ibadan, Nigeria.

IITA (1997). Annual Report 1997 (Project 12). Improvement of maize/grain legume production systems in the moist savanna of west and central Africa.

IITA (1999). Annual Report 1999 (Project 11). Cowpea-cereals systems improvement in the savannas.

IITA (2000). Annual report 2000 (Project 4). Improving maize-grain legume systems in west and central Africa.

IITA (2003). Annual report 2003 (Project A).

Kueneman, E. A.; Root, W. R.; Dashiell, K. E. \& Hohenberg, J. (1984). Breeding soybean for the tropics capable of nodulating effectively with indigenous Rhizobium spp. Plant and Soil, 82, 3 (October 1984) 387-396, ISSN: 0032 - 079X.

Ogoke, I. J.; Carsky, R. J.; Togun, A. O. \& Dashiell, K. (2001). Enhancing soybean residue contribution to soil fertility using phosphate fertilizer application. Proceedings of the $5^{\text {th }}$ African Crop Science Conference, pp. 1085-1088, ISBN 10 9780061630, Le Meridien Eko Hotel, Victoria Island, Lagos, Nigeria, October 21-26, 2001, African Crop Science Society.

Ogoke, I. J.; Carsky, R. J.; Togun, A. O. \& Dashiell, K. (2003). Effect of P fertilizer application on $\mathrm{N}$ balance of soybean crop in the Guinea savanna of Nigeria. Agriculture, Ecosystems and Environment, 100, 2-3, (December 2003) 153-159, ISSN: 0167 - 8809.

Osunde, A. O.; Bala, A.; Gwam, M. S.; Tsado, P. A.; Sanginga, N. \& Okogun, J. A. (2003). Residual benefits of promiscuous soybean to maize (Zea mays L.) grown on farmers' fields around Minna in the southern Guinea savanna zone of Nigeria. Agriculture Ecosystems and Environment, 100, 2-3, (December 2003) 209-220, ISSN: 0167 - 8809.

Pulver, E. L., Brockman, F. \& Wien, H. C. (1982). Nodulation of soybean cultivars with Rhizobium spp. and their response to inoculation with $R$. japonicum. Crop Science, 22, 5, (September - October 1982) 1065-1070, ISSN: 0011 - 183X. 
Pulver, E. L., Kueneman, E. A. \& Ranga-Rao, V. (1985). Identification of promiscuous nodulating soybean efficient in $\mathrm{N}_{2}$ fixation. Crop Science, 25, 4, (July-August 1985) 660-663, ISSN: 0011 - 183X.

Sanginga, N., Dashiell, K.; Okogun, J. A. \& Thottappilly, G. (1997). Nitrogen fixation and N contribution by promiscuous nodulating soybeans in the southern Guinea savanna of Nigeria. Plant and Soil, 195, 2, (August 1997) 257-266, ISSN: 0032 - 079X.

Sanginga, N.; Thottappilly, G. \& Dashiell, K. (2000). Effectiveness of rhizobia nodulating recent promiscuous soyabean selections in the moist savanna of Nigeria. Soil Biology \& Biochemistry, 32, 1, (January 2000) 127-133, ISSN: 0038 - 0717.

Sanginga, N.; Okogun, J.; Vanlauwe, B. \& Dashiell, K. (2002). The contribution of nitrogen by promiscuous soybeans to maize based cropping in the moist savanna of Nigeria. Plant and Soil, 241, 2, (April 2002): 223-231, ISSN: 0032 - 079X.

Sanginga, N. (2003). Role of biological nitrogen fixation in legume based cropping systems; a case study of West Africa farming systems. Plant and Soil, 252, 1, (May 2003): 25-39.

Tefera, H.; Kamara, A. Y.; Asafo-Adjei, B. \& Dashiell, K. E. (2009). Improvement in grain and fodder yields of early maturing promiscuous soybean varieties in the Guinea savanna of Nigeria. Crop Science, 49, 6, (November - December 2009) 2037-2042, ISSN: 0011 - 183X.

Tefera, H.; Kamara, A. Y.; Asafo-Adjei, B. \& Dashiell, K. E. (2010). Breeding progress for grain yield and associated traits in medium and late maturing promiscuous soybeans in Nigeria. Euphytica, 175, 2, (September 2010) 251-260, ISSN: 0014 - 2336.

Tukamuhabwa, P., Rubaihayo, P. R.; Dashiell, K. \& Adipala, E. (2000). Inheritance of resistance to pod shattering in soybean. African Crop Science Journal, 8, 3, (2000) 203211, ISSN 1021 - 9730.

Tukamuhabwa, P., Rubaihayo, P. R. \& Dashiell, K. E. (2002). Genetic components of pod shattering in soybean. Euphytica, 125, 1, (May 2002) 29-34, ISSN: 0014 - 2336. 


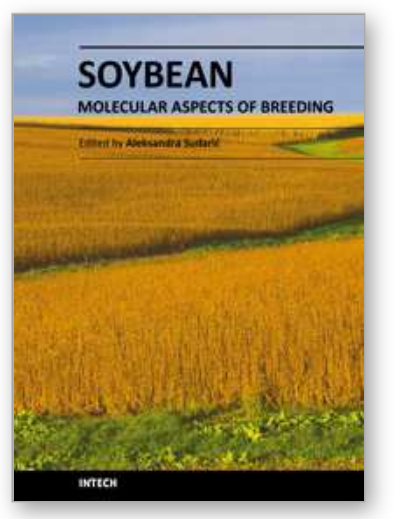

\author{
Soybean - Molecular Aspects of Breeding \\ Edited by Dr. Aleksandra Sudaric
}

ISBN 978-953-307-240-1

Hard cover, 514 pages

Publisher InTech

Published online 11, April, 2011

Published in print edition April, 2011

The book Soybean: Molecular Aspects of Breeding focuses on recent progress in our understanding of the genetics and molecular biology of soybean and provides a broad review of the subject, from genome diversity to transformation and integration of desired genes using current technologies. This book is divided into four parts (Molecular Biology and Biotechnology, Breeding for Abiotic Stress, Breeding for Biotic Stress, Recent Technology) and contains 22 chapters.

\title{
How to reference
}

In order to correctly reference this scholarly work, feel free to copy and paste the following:

Hailu Tefera (2011). Breeding for Promiscuous Soybeans at IITA, Soybean - Molecular Aspects of Breeding, Dr. Aleksandra Sudaric (Ed.), ISBN: 978-953-307-240-1, InTech, Available from: http://www.intechopen.com/books/soybean-molecular-aspects-of-breeding/breeding-for-promiscuoussoybeans-at-iita

\section{INTECH}

open science | open minds

\author{
InTech Europe \\ University Campus STeP Ri \\ Slavka Krautzeka 83/A \\ 51000 Rijeka, Croatia \\ Phone: +385 (51) 770447 \\ Fax: +385 (51) 686166 \\ www.intechopen.com
}

\author{
InTech China \\ Unit 405, Office Block, Hotel Equatorial Shanghai \\ No.65, Yan An Road (West), Shanghai, 200040, China \\ 中国上海市延安西路65号上海国际贵都大饭店办公楼 405 单元 \\ Phone: +86-21-62489820 \\ Fax: $+86-21-62489821$
}


(C) 2011 The Author(s). Licensee IntechOpen. This chapter is distributed under the terms of the Creative Commons Attribution-NonCommercialShareAlike-3.0 License, which permits use, distribution and reproduction for non-commercial purposes, provided the original is properly cited and derivative works building on this content are distributed under the same license. 